\title{
A STUDY ON THE IMPACT OF MONETARY POLICY ON BANK DEPOSITS
}

\author{
Anirban Ghatak*
}

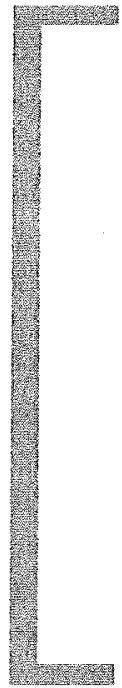

\section{ABSTRACT}

Despite 125 years of capital market experience, 83.9 per cent of households in India still invest only in the safe and sound bank deposits. While only 7.2 per cent of the households were investing in the capital market. Radical transformations had occurred in India's capital market in the meanwhile. At around $\$ 780$ billion, India's GDP (gross domestic product) is comparable to that of South Korea; yet Korean banks have seven times more banking assets than Indian banks. With assets of around Rs 4,93,000 crore, State Bank of India (SBI) is the country's largest bank, yet it is only ranked 84 in the world, according to The Banker; the next biggest is $\mathrm{ICIClBank,} \mathrm{which} \mathrm{is} \mathrm{half} \mathrm{the} \mathrm{size} \mathrm{of} \mathrm{SBI} \mathrm{and}$ ranked around 200 globally.

Therefore it can be concluded that, India is still an 'unbanked' country and by global standards, even the biggest of Indian banks are minnows in a business where size means clout and where geographical boundaries

* Lecturer, Institute of Management, Christ University, Bangalore 
are blurring. Even by Indian standards, most of the banking sector is disadvantaged by size: the top 25 banks - of which, 18 are owned by the government - account for about 85 per cent of banking assets.

Monetary policy is generally referred to as either being an expansionary policy, or a contractionary policy, where an expansionary policy increases the total supply of money in the economy, and a contractionary policy decreases the total money supply. Monetary management in India has become a far more complex task today than what it was say, a decade ago. The pressures on monetary expansion are emanating largely from external sector and these have far reaching implications for not only monefary management but also for exchange rate management. The inter-connectedness of the two is posing a dilemma to the Central Bank. Tackling such a situation therefore warrants a different mix of policy instruments.

The study aims at understanding the impact of various monetary measures on bank deposits. The study of monetary policy and its variables along with various bank deposit schemes was carried out from literature.

\section{Introduction}

At first glance, India's financial sector is doing extremely well. Banks have doubled their loan assets in four years and the price-to-book value of Indian banks is second only to China. But the irony is that despite so much growth and wealth creation, two-thirds of the country continues to have no access to organized financial services. According to a report by the Boston Consultancy Group (BCG), India has the second highest number of financially-excluded households in the world of about 135 million, which is second only to China. India's financial sector is growing very rapidly it is the fastest-growing incremental revenue pool in the world, growing at a rate faster than even China.But barely $35 \%$ households are truly included and have access to financial services from the formal sector. Financial services may have taken off for financial institutions, but has not taken off for India and all Indians. The worse part is that, last decade's record growth in financial services has widened the gap between urban and rural India. Since 1999, bank deposits have grown 3.75 times to Rs 29.29 trillion, but it is the cities where bank deposits have been piling up. According to a report of Karvy Stock broking, Top 10 cities which accounted for only $50 \%$ of bank deposits in 1999 today account for over $60 \%$. Metros have 
emerged as the largest beneficiaries of the high economic growth in India, as corporatism posted robust performances resulting in higher corporate savings. The change in ideological profile of Indian banks, post-liberalization, has also diluted the focus of state-owned banks on rural credit. After losing their 'creamy layer' to private banks, state-owned banks have also begun to structure themselves in the form of new private banks. Many of them increased their minimum balance requirements, prompting the central bank to come out with a diktat asking banks to open 'no-frills' accounts with minimum or zero balance. Most private banks have introduced such 'nofrills' accounts only to fulfill statutory requirement and have made no effort to publicize the availability of such a product. As a result, there is move to build a business providing financial services to those who are at present financially excluded.

Traditionally, the process of monetary policy in India had been largely internal with only the end product of actions being made public. A process of openness was initiated by Governor Rangarajan and has been widened, deepened and intensified by Governor Jalan. The process has become relatively more articulate, consultative and participative with external orientation, while the internal work processes have also been re-engineered to focus on technical analysis, coordination, horizontal management, rapid responses and being market savry.

Although there has not been any explicit legislation for price stability, the major objectives of monetary policy in India have been those of maintaining price stability and ensuring adequate flow of credit to the productive sectors of the economy. The relative emphasis between the objectives depends on the underlying economic conditions and is spelt out from time to time. Compared to many other developing economies, India has been able to maintain a moderate level of inflation. Historically, inflation rates in India rarely touched double digit and when they did, in most cases, they were the result of supply shocks either in the form of increase in agricultural commodity prices or in the form of increase in international prices of crude oil. The conduct of monetary policy has become more challenging in recent years for a variety of reasons. Many of the challenges the central banks are facing are almost similar which could be summarized in the two broad headings which are as follows:

- Challenges with globalization

- Challenges for Emerging Market Economies 


\section{Review of Literature}

Economists have devoted significant attention to the different contagion channels of monetary policy. A second line of thinking analyzes bank behavior in response to monetary shocks. It is likely that smaller banks have more trouble attracting external funds during a monetary contraction (Kashyap and Stein, 1997). The final strand of research analyzes the response of corporate financial structure to changes in monetary regimes. These studies have focused on the US economy (Kashyap et al., 1996; Oliner and Rudebusch, 1996). Kashyap et al. (1993) empirically examine the existence of a loan supply (or a bank lending) channel of monetary policy transmission for the U.S. economy for the period 1974-98.

In the Indian context, there have been several studies on the analytics of monetary policy (Rangarajan, 1988; Reddy, 2002), the financing pattern of corporate houses (Cobham and Subramaniam, 1998), as well as the role of large shareholders in corporate governance (Sarkar and Sarkar, 2000 ), and the different corporate governance pattern in public versus private banks (Jalan, 2002). Topalova (2004) provides an analytical overview of the Indian corporate sector for the period 1989-2002 and finds a weakening of corporate sector performance (in terms of profitability) post 1997.

The study aims at understanding the impact of various monetary measures on bank deposits. The study of monetary policy and its variables along with various bank deposit schemes was carried out from literature.

\section{Design of the Study}

\section{Objective of the Study}

\section{Primary Objective}

- To study the impact of the monetary measures on bank deposits in terms of investment

\section{Secondary Objective}

- Study of different monetary measures taken by the Central Bank.

- Study of different band deposit schemes available to investors. 
- Importance of bank deposits on the economic growth and sustainability.

- Comparison of various investment options with bank deposits.

- The change in preferences of respondents in terms of investments in bank deposits due to change in monetary variables.

- To give recommendations based on the findings of the study.

\section{Hypothesis}

\section{Hypothesis 1}

$\mathrm{HO}$ : Investment in bank deposits and stock markets is independent.

$\mathrm{HI}$ : Investment in Bank Deposits and Stock Market is related to each other.

\section{Hypothesis 2}

$\mathrm{HO}$ : Expected Returns does not vary with annual income and age of respondent.

$H 1$ : Expected returns vary with age and income of the respondent.

\section{Hypothesis 3}

$\mathrm{HO}$ : Change in investment in bank deposits is due to investment in stock market

$\mathrm{H1}$ : Change in investment in bank deposits is not due to investment in stock market

\section{Limitations of Study}

- The respondents may not disclose the correct information and may get biased.

- Difficult to deduce results based on small sample size.

- Location and time constraints may limit the study.

- Results concluded may not be applicable to entire population.

- Certain variables may have been ignored. 


\section{Data Analysis and Interpretation}

\section{Analysis of Questionnaire}

1. Do you invest your savings in banks?

Table 1 depicts whether the respondents invest their savings in banks

\begin{tabular}{|c|c|}
\hline Choice & No. of Respondents \\
\hline Yes & 75 \\
No & 0 \\
\hline
\end{tabular}

Interpretation:

Out of 75 respondents, all 75 have selected "Yes" and none have selected "No". As only those respondents were part of the research who actually invests their savings in banks, in order to carry out the study.

2. Which bank deposit scheme do you prefer for investing? Table 2 shows the investor's preference for bank deposit schemes.

\begin{tabular}{|l|c|}
\hline Bank Deposit Scheme & No. of Respondents \\
\hline Savings Deposit & 15 \\
Fixed Deposit & 22 \\
Term Deposit & 26 \\
Current Deposit & 10 \\
\hline
\end{tabular}

Interpretation:

A majority of the respondents, i.e. $37 \%$ prefer term deposits, closely followed by fixed deposits (29\%). Only $20 \%$ of the respondents prefer savings deposit scheme, which is followed by current deposits which are preferred by least number of investors i.e., 13\%.

3. Has there been any change in your investments in bank deposits in this financial year compared to the previous financial year?

Table 3 depicts the change perceived by the investors in their investments in bank deposits 


\begin{tabular}{|c|c|}
\hline Choice & No. of Respondents \\
\hline Increased & 24 \\
Decreased & 25 \\
No Change & 26 \\
\hline
\end{tabular}

Interpretation:

There is not much difference between the numbers of respondents view regarding the change of their investments in their respective bank deposits. $35 \%$ of the total respondents state that their investments have not changed, while $33 \%$ of respondents have noticed a decrease I their bank deposit investments and only $32 \%$ state that their investments have rather increased in their bank deposits.

4. Which banks do you prefer for investment in bank deposits?

Table .4 depicts the preference of banks for investment in bank deposits through mean.

\begin{tabular}{|l|c|}
\hline \multicolumn{1}{|c|}{ Bank } & Mean \\
\hline Public Sector Banks & \\
Private Sector Banks & 2.29 \\
Foreign Bank & 2.13 \\
\hline
\end{tabular}

Interpretation:

A majority of the respondents have their first preference as public sector banks, followed by private sector banks, while only very few prefer foreign bank. As this was a ranking question, hence means were taken for each option.

5. Do you know that CRR is used to control liquidity situation in an economy?

Table 5 depicts whether the investor is aware that CRR is used to control liquidity situation in an economy:

\begin{tabular}{|c|c|}
\hline Choice & No. of Respondents \\
\hline Yes & 58 \\
No & 17 \\
\hline
\end{tabular}


Interpretation:

$77 \%$ of the total respondents are aware about the role of CRR, while only a handful, i.e. $23 \%$ of respondents are not aware about the function of CRR. CRR is Cash Reserve Ratio and is used to control liquidity situation in an economy.

6. In which category do you see yourself as a risk taker?

Table 6 shows the preference of respondents in form of statements

\begin{tabular}{|c|c|}
\hline Statement & No. of Respondents \\
\hline 1 & 39 \\
2 & 36 \\
\hline
\end{tabular}

Interpretation:

A majority of respondents prefer statement 1 rather than statement2. Therefore a majority of respondents feel that they would withdraw money from bank deposits and invest in stock market when it goes up, rather than withdraw money from stock market and deposit in banks when the stock market goes down.

7. How do you consider the following investment options in terms of safety of investments?

Table 7 depicts the response of the 'respondent with respect to various investment options in terms of safety of investments through mean.

\begin{tabular}{|l|c|}
\hline \multicolumn{1}{|c|}{ Investment Option } & Mean \\
\hline Money Market & 1.39 \\
Bank Deposits & 1.49 \\
DebtMarket & 1.52 \\
Insurance & 1.72 \\
Gold & 2.13 \\
Derivatives & 2.32 \\
Real Estate & 2.59 \\
Stock Exchange & 3.27 \\
Commodities & 4.52 \\
\hline
\end{tabular}


Interpretation:

Based on the average obtained for the different investment options, Commodities is considered to be the riskiest, followed by Stock Exchange. is considered to be the riskiest for investment. Real Estate, Derivatives and Gold are also considered risky. While Insurance, Debt Market, Bank Deposits are considered to be safe. And Money Market is considered to be safest.

8. Reaction to fluctuations in interest rates.

Table 8 depicts the reaction of respondents due to fluctuations in interest rates.

\begin{tabular}{|l|c|}
\hline \multicolumn{1}{|c|}{ Reaction } & No. of Respondents \\
\hline Extremely Uneasy & 3 \\
Very Concerned & 19 \\
Some Worries & 32 \\
Very Litlle Concern & 21 \\
\hline
\end{tabular}

Interpretation:

Almost $43 \%$ of the respondents feel that they will have some worries, $28 \%$ of the respondents feel that they will have very little concern, $25 \%$ feel that they will be very concerned and only a handful, i.e. $4 \%$ feel that they will be extremely uneasy, due to fluctuations in interest rates which shall affect the value of their investments in bank deposits. This also indirectly reflects the risk appetite as well as the portion held by bank deposits as part of portfolio of investments of a particular investor.

9. What are the returns that you expect from your investments?

Table 9 depicts the returns expected by the respondent from his/ her respective investments.

\begin{tabular}{|c|c|}
\hline Expected Returns & No. of Respondents \\
\hline $5-10 \%$ & 3 \\
$11-15 \%$ & 17 \\
$16-24 \%$ & 33 \\
More than 25\% & 21 \\
\hline
\end{tabular}


Interpretation:

$45 \%$ of the respondents prefer $16-24 \%$ returns from their investments, $28 \%$ expect more than $25 \%$, while only $23 \%$ expect $11-15 \%$ returns and only $4 \%$ expect $5-10 \%$. This indicates that the respondents are not investing only in bank deposits but have a diversified portfolio of investments.

\section{Preference of maturity of deposits}

Table 10 depicts the preference of maturity of deposits of the respondents.

\begin{tabular}{|l|c|}
\hline \multicolumn{1}{|c|}{ Maturity Period } & No. of respondents \\
\hline Upto 90 days & 19 \\
91 days-6 months & 14 \\
6 months- -1 year & 22 \\
1 year -2 year & 23 \\
2 years-3 years & 10 \\
3 years -5 years & 6 \\
5 years and above & 1 \\
\hline
\end{tabular}

Interpretation:

A majority of the respondents prefer deposits of 1 year -2 years, closely followed by 6 months- 1 year. Deposits of shorter duration of up to 90 days are also preferred by a major number of respondents. While 91 days -6 months are preferred next. On the other hand deposits of longer duration are preferred in the order of 2 years -3 years, 3 years- 5 years and 5 years \& above.

\section{Do you think that interest rates on savings account should be} regulated by $\mathrm{RBI}$ ?

Table 11 shows the preference of respondents in terms of regulation of interest rates by RBI.

\begin{tabular}{|c|c|}
\hline Response & No. of Respondents \\
\hline Yes & 54 \\
No & 21 \\
\hline
\end{tabular}


Interpretation:

$72 \%$ of the respondents prefer regulation of interest rates to be continued by $\mathrm{RBI}$, while $28 \%$ feel that the interest rates should be market driven rather than being controlled by RBI.

\section{Factors considered while making investments}

Table 12 depicts the factors considered by the respondents while making investments and the corresponding mean weighted ranks.

\begin{tabular}{|l|c|}
\hline \multicolumn{1}{|c|}{ Factor } & Mean \\
\hline Security & 3.69 \\
Tax Saving & 3.6 \\
Liquidity & 3.16 \\
Risk Appetite & 2.45 \\
Investment Style & 2.16 \\
\hline
\end{tabular}

Interpretation:

A majority of investors have ranked Security of investments higher than all other factors which has a mean of 3.69, closely followed by Tax Saving which has a mean of 3.6. This is followed by Liquidity. Risk appetite is considered less important by a majority of respondents and Investment Style is considered the least important.

13. Grading of banks in terms of preference / performance with respect to bank deposits

Table 13 depicts the respondent's response for bank deposits in terms of preference/performance with respect to bank deposits.

\begin{tabular}{|l|c|}
\hline \multicolumn{1}{|c|}{ Bank } & Mean \\
\hline HDFC Bank & 3.9 \\
State Bank of India & 3.84 \\
ICICI Bank & 3.77 \\
Standard Chartered & 3.51 \\
HSBC Bank & 3.32 \\
Canara Bank & 3.24 \\
IDBI Bank & 3.23 \\
Axis Bank & 3.19 \\
Citibank & 3.13 \\
Bank of Baroda & 3.08 \\
\hline
\end{tabular}


Interpretation:

A majority of respondents have graded HDFC bank very good compared to all other banks. This is followed by SBI which is the best among the public sector banks. Among the foreign banks Standard Chartered has been considered good compared to other foreign banks.

\section{Correlation Analysis}

1. Correlation between expected returns from investments and various factors considered while making investments.

Table 14 indicates the correlation between expected returns from investments and various factors considered while making investments.

\begin{tabular}{|l|r|r|r|r|r|r|}
\hline & Returns & Liquidity & $\begin{array}{c}\text { Tax } \\
\text { Saving }\end{array}$ & Security & $\begin{array}{c}\text { Invest- } \\
\text { ment } \\
\text { Style }\end{array}$ & $\begin{array}{c}\text { Risk } \\
\text { Appetite }\end{array}$ \\
\hline Returns & 1 & & & & & \\
Liquidity & 0.14 & 1 & & & & \\
Tax Saving & -0.04 & -0.05 & 1 & & & \\
Security & -0.15 & -0.31 & -0.15 & 1 & & \\
Investment Style & 0.17 & -0.18 & -0.35 & -0.34 & 1 & \\
Risk Appetite & -0.12 & -0.39 & -0.21 & -0.23 & -0.18 & 1 \\
\hline
\end{tabular}

Interpretation:

- There is a low degree of positive correlation between the expected returns and liquidity. This implies that as expected returns increase, liquidity becomes an important factor considered for investment.

- There also exists a low degree of positive correlation between expected returns and investment style. This implies that as expected returns increases, style of investment also becomes an important factor for investment.

- Since there exists a high degree of negative correlation between expected returns and tax saving, it can be interpreted that as the expected returns increase, tax saving is considered less important for investment. 
- The correlation between expected returns and risk appetite is also negative, hence its importance as a factor considered while making investment decreases.

- There exists a very low degree of negative between expected returns and security, its importance as a factor for making investment from which high returns are expected decreases.

2. Correlation between the investor's reaction to fluctuation in interest rates and the expected returns from investments

Table 15 indicates the correlation between the investor's reaction to fluctuation in interest rates and the expected returns from investments

\begin{tabular}{|l|c|c|}
\hline & Reaction & Returns \\
\hline $\begin{array}{l}\text { Reaction } \\
\text { Returns }\end{array}$ & 1 & 1 \\
\hline
\end{tabular}

Interpretation:

There is a low degree of positive correlation between the investor's reactions to fluctuation in interest rates and the returns expected from investments.

This implies that as the respondent becomes less concerned to fluctuation in interest rates his/ her expectations from investments in form of returns also increase. Hence this can be stated as that if an individual is less concerned regarding fluctuation to interest rates, his expected returns from his investment is increasing which means he/she has invested in areas other than those which are directly affected by interest rates.

3. Correlation between the preference for a specific sector bank and the expected returns from investments.

Table 16 indicates the correlation between the preference for a specific sector bank and the expected returns from investments.

\begin{tabular}{|l|r|r|r|c|}
\hline & Public & Private & Foreign & Returns \\
\hline Public & 1 & & & \\
Private & -0.400 & 1 & & \\
Foreign & -0.645 & -0.429 & 1 & \\
Returns & -0.107 & 0.0148 & 0.09 & 1 \\
\hline
\end{tabular}


Interpretation:

- There exists a low degree of negative correlation between preference for a public sector bank and expected returns from investments. This implies that as the preference for public sector banks increases, the expected returns from investment also moves towards lower side.

- The correlation between preference for private sector bank and expected returns is positive but of very low degree. This implies that higher preference for private sector banks is due to increasing expected returns from investments.

- There is a low degree of positive correlation between the preference for foreign bank and expected returns. This implies that people prefer foreign banks because of their increasing returns expected from their investments.

- The correlation between public sector and private sector bank is negative and of low degree. Hence as preference for private sector bank increases, it leads to a consecutive lower preference for public sector banks.

- There exists a low degree of negative correlation between public sector bank and private sector bank. As preference for foreign bank increases, there shall be low preference for public sector banks.

- The correlation between private sector bank and foreign bank is of low degree and is negative which implies that as people prefer more of private sector banks, they shall foreign banks but to a lesser degree.

\section{Chi-Square Analysis}

1. Chi-Square Analysis to test the dependence of expected returns on the annual income of investor ( $Q 9 \&$ \& 17)

$\mathrm{HO}$ : Expected return is independent of the annual income of the investor.

$\mathrm{Hl}$ : Expected return is dependant on the annual income of the investor.

Table 17 indicating the expected returns according to the annual income of the investor 


\begin{tabular}{|c|l|r|r|r|r|r|}
\hline TABLE & \multicolumn{6}{|c|}{ Expected Returns } \\
\hline & & $5-10 \%$ & $11-15 \%$ & $16-24 \%$ & $>25 \%$ & \\
\cline { 2 - 7 } & $<150000$ & 2 & 4 & 1 & 2 & 9 \\
Annual & $150001-3500000$ & 1 & 3 & 10 & 0 & 14 \\
Income & $350001-5000000$ & 0 & 4 & 5 & 2 & 11 \\
& $500001-1000000$ & 0 & 2 & 7 & 5 & 14 \\
& 1000001 & 0 & 4 & 10 & 12 & 26 \\
& & 3 & 17 & 33 & 21 & 74 \\
\hline
\end{tabular}

Chi-Square Value: 26.01

Table Value: 21.026

Interpretation: As the Chi-Square is greater than the table value, the null hypothesis rejected and the alternate hypothesis $(\mathrm{HI})$ is accepted. Thus it can be interpreted that the expected returns of the investor is dependant on his/her annual income.

2. Chi-Square analysis to test the dependence of expected returns on the age of the respondent (Q9 \& Q14)

HO: Expected Returns is independent of the age profile

$\mathrm{H}$ : Expected Returns is dependent on the age profile

Table 18 depicts the Expected Returns of the respondent according to the age profile.

\begin{tabular}{|l|l|r|r|r|r|r|}
\hline TABLE & \multicolumn{7}{|c|}{ Expected Returns } \\
\hline \multirow{3}{*}{} & & $5-10 \%$ & $11-15 \%$ & $16-24 \%$ & $>25 \%$ & \\
\cline { 2 - 7 } & $<20$ & 0 & 1 & 1 & 1 & 3 \\
& $21-35$ & 1 & 9 & 17 & 7 & 34 \\
& $36-50$ & 1 & 5 & 10 & 12 & 28 \\
& $>51$ & 1 & 2 & 5 & 1 & 9 \\
& & 3 & 17 & 33 & 21 & 74 \\
\hline
\end{tabular}

Chi-Square Value: 6.802

Table Value: 16.919

Interpretation: Since calculated value is less than table value, the null hypothesis $(\mathrm{HO})$ is accepted. Hence the expected returns are independent of the age of the respondent. 
3. Chi-Square test to test the dependence of choice of bank deposit scheme on the age of the respondent (Q2 \& Q14)

HO: The choice of bank deposit scheme is independent on the age profile of the respondent

$\mathrm{H1}$ : The choice of bank deposit scheme is dependent on the age profile of the respondent

Table 19 indicates the choice of bank deposit scheme according to the age profile of the respondent

\begin{tabular}{|c|l|r|r|r|r|r|}
\hline TABLE & \multicolumn{6}{|c|}{ Bank Deposit Scheme } \\
\hline \multirow{3}{*}{ Age } & & \multicolumn{6}{|c|}{$\begin{array}{c}\text { Savings } \\
\text { Deposit }\end{array}$} & $\begin{array}{c}\text { Fixed } \\
\text { Deposit }\end{array}$ & $\begin{array}{c}\text { Term } \\
\text { Deposit }\end{array}$ & $\begin{array}{r}\text { Current } \\
\text { Deposit }\end{array}$ \\
\cline { 2 - 8 } & $<20$ & 1 & 0 & 2 & 0 & 3 \\
& $21-35$ & 5 & 11 & 14 & 4 & 34 \\
& $36-50$ & 6 & 8 & 10 & 5 & 29 \\
& $>51$ & 3 & 3 & 2 & 1 & 9 \\
& & 15 & 22 & 28 & 10 & 75 \\
\hline
\end{tabular}

Chi-Square Value: 4.883

Table Value: 16.919

Interpretation: Since calculated value of Chi-Square is less than the table value. $\mathrm{HO}$ is accepted. Hence it can be interpreted as that the choice of bank deposit scheme is independent of the age of the respondent.

4. Chi-Square test to test the dependence of choice of bank deposit scheme on the gender of the respondent (Q2 \& Q15)

HO: The choice of bank depositscheme is independent on the gender of the respondent

$\mathrm{HI}$ : The choice of bank deposit scheme is dependent on the gender of the respondent

Table 20 indicates the choice of bank deposit scheme according to the gender of the respondent 


\begin{tabular}{|c|l|r|r|r|r|r|}
\hline TABLE & \multicolumn{6}{|c|}{ Question A } \\
\hline & & $\begin{array}{r}\text { Savings } \\
\text { Deposit }\end{array}$ & $\begin{array}{c}\text { Fixed } \\
\text { Deposit }\end{array}$ & $\begin{array}{c}\text { Term } \\
\text { Deposit }\end{array}$ & $\begin{array}{c}\text { Current } \\
\text { Deposit }\end{array}$ \\
\cline { 2 - 7 } & & 11 & 18 & 21 & 8 & 58 \\
Question B & Male & 4 & 4 & 7 & 2 & 17 \\
& Female & 15 & 22 & 28 & 10 & 75 \\
\hline
\end{tabular}

Chi-Square Value: 0.517

Table Value: 7.815

Interpretation: Since calculated value of Chi-Square is less than the table value. $\mathrm{HO}$ is accepted. Hence it can be interpreted as that the choice of bank deposit scheme is independent of the gender of the respondent.

5. Chi-Square test to test the dependence of choice of bank deposit scheme on the occupation of the respondent (Q2 \& Q16)

HO: The choice of bank deposit scheme is independent of the occupation of the respondent

$\mathrm{H1}$ : The choice of bank deposit scheme is dependent on the occupation of the respondent

Table 21 indicates the choice of bank deposit scheme according to the occupation of the respondent

\begin{tabular}{|c|l|r|r|r|r|r|}
\hline \multirow{2}{*}{ TABLE } & \multicolumn{6}{|c|}{ Question A } \\
\hline & & $\begin{array}{c}\text { Savings } \\
\text { Deposit }\end{array}$ & $\begin{array}{c}\text { Fixed } \\
\text { Deposit }\end{array}$ & $\begin{array}{c}\text { Term } \\
\text { Deposit }\end{array}$ & $\begin{array}{c}\text { Current } \\
\text { Deposit }\end{array}$ \\
& & 0 & 6 & 6 & 5 & 17 \\
\cline { 2 - 7 } Question B & Business & 5 & 5 & 10 & 1 & 21 \\
& Professional & 9 & 11 & 11 & 4 & 35 \\
& Employee & 1 & 0 & 1 & 0 & 2 \\
& Student & 0 & 0 & 0 & 0 & 0 \\
& Others & 15 & 22 & 28 & 10 & 75 \\
\hline
\end{tabular}

Chi-Square Value: 11.93

Table Value: 21.026

Interpretation: Since calculated value of Chi-Square is less than the table value. $\mathrm{HO}$ is accepted. Hence it can be interpreted as that the choice of bank deposit scheme is independent of the occupation of the respondent. 
6. Chi-Square test to test the dependence of choice of bank deposit scheme on the annual income of the respondent (Q2 \& Q17)

HO: The choice of bank deposit scheme is independent of the annual income of the respondent

$\mathrm{H1}$ : The choice of bank deposit scheme is dependent of the annual income of the respondent

Table 22 indicates the choice of bank deposit scheme according to the occupation of the respondent

\begin{tabular}{|c|c|c|c|c|c|c|}
\hline TABLE & \multicolumn{6}{|c|}{ Question A } \\
\hline \multirow{7}{*}{ Question B } & & $\begin{array}{l}\text { Savings } \\
\text { Deposit }\end{array}$ & $\begin{array}{c}\text { Fixed } \\
\text { Deposit }\end{array}$ & $\begin{array}{c}\text { Term } \\
\text { Deposit }\end{array}$ & $\begin{array}{l}\text { Current } \\
\text { Deposit }\end{array}$ & \\
\hline & $<150000$ & 2 & 1. & 4 & 2 & 9 \\
\hline & $150001-350000$ & 2 & 5 & 4 & 3 & 14 \\
\hline & $350001-50000$ & 1 & 3 & 5 & 2 & 11 \\
\hline & $50001-100000$ & 4 & 3 & 6 & 1 & 14 \\
\hline & $>100001$ & 6 & 10 & 9 & 2 & 27 \\
\hline & & 15 & 22 & 28 & 10 & 75 \\
\hline
\end{tabular}

Chi-Square Value: 6.923

Table Value: 21.026

Interpretation: Since calculated value of Chi-Square is less than the table value. $\mathrm{HO}$ is accepted. Hence it can be interpreted as that the choice of bank deposit scheme is independent of the annual income of the respondent.

\section{ANOVA Analysis}

1. ANOVA between the change in investments in bank deposits (Q3) and investment in stock markets (Q6)

$\mathrm{HO}$ : There is no significant difference between the change in investments in bank deposits and investment in stock market.

$\mathrm{H1}$ : There is a significant difference between the change in investments in bank deposits and investment in stock market. 
Table 23 depicts the sources of variance for the change in investments in bank deposits and investment in stock market.

\begin{tabular}{|l|r|r|r|l|}
\hline Groups & Count & \multicolumn{1}{|c|}{ Sum } & Average & Variance \\
\hline Change & 75 & 152 & 2.026667 & 0.674955 \\
Stock Market & 75 & 111 & 1.48 & 0.252973 \\
\hline
\end{tabular}

\begin{tabular}{|l|c|c|c|c|c|c|}
\hline $\begin{array}{l}\text { Source of } \\
\text { Variation }\end{array}$ & SS & df & MS & F & P-value & F crit \\
\hline $\begin{array}{l}\text { Between } \\
\text { Groups }\end{array}$ & 11.20667 & 1 & 11.20667 & 24.15417 & $2.33 E-06$ & 3.90506 \\
$\begin{array}{l}\text { Within } \\
\text { Groups }\end{array}$ & 68.66667 & 148 & 0.463964 & & & \\
Total & 79.87333 & 149 & & & & \\
\hline
\end{tabular}

Interpretation: As the $F(24.15)>$ Fcrit (3.9), we reject $\mathrm{HO}$ and conclude that there is a significant difference between the change in investments in bank deposits in this financial year compared to previous financial year and investment in stock market which shall affect the value of investment in bank deposit in a bullish and a bearish trend.

2. ANOVA between preference of bank deposit scheme (Q2) and Occupation of the respondent (16)

H0: There is no significant difference between the preference of bank deposit scheme and the occupation of the respondent

$\mathrm{H1}$ : There is significant difference between the preference of bank deposit scheme and the occupation of the respondent

Table 24 depicts the sources of variance for preference of bank deposit scheme and the occupation of the respondesnt 


\begin{tabular}{|l|c|c|r|r|}
\hline Groups & Count & Sum & \multicolumn{1}{|c|}{ Average } & Variance \\
\hline Deposit Scheme & 75 & 183 & 2.44 & 0.925405 \\
Occupation & 75 & 172 & 2.293333333 & 0.723604 \\
\hline
\end{tabular}

\begin{tabular}{|l|r|r|r|r|r|r|}
\hline $\begin{array}{l}\text { Source of } \\
\text { Variation }\end{array}$ & S S & df & MS & F & P-value & F crit \\
\hline $\begin{array}{l}\text { Between } \\
\text { Groups } \\
\text { Within } \\
\text { Groups } \\
\text { Total }\end{array}$ & 0.806666667 & 1 & 0.806666667 & 0.978365 & 0.324217 & 3.90506 \\
\hline
\end{tabular}

Interpretation:

Since $F(0.978)<F c r i t(3.905)$, the null hypothesis is accepted.

Hence it can be concluded that there is no significant difference between the preference of bank deposit scheme and the occupation of the respondent.

\section{Findings of the study:}

- There is a low degree of positive correlation between the expected returns and liquidity. This implies that as expected returns increase, liquidity becomes an important factor considered for investment.

- There also exists a low degree of positive correlation between expected returns and investment style. This implies that as expected returns increases, style of investment also becomes an important factor for investment.

- Since there exists a high degree of negative correlation between expected returns and tax saving, it can be interpreted that as the expected returns increase, tax saving is considered less important for investment.

- The correlation between expected returns and risk appetite is also negative, hence its importance as a factor considered while making investment decreases. 
- There exists a very low degree of negative between expected returns and security, its importance as a factor for making investment from which high returns are expected decreases.

- There is a low degree of positive correlation between the investor's reactions to fluctuation in interest rates and the returns expected from investments. This implies that as the respondent becomes less concerned to fluctuation in interest rates his/ her expectations from investments in form of returns also increase. Hence this can be stated as that if an individual is less concerned regarding fluctuation to interest rates, his expected returns from his investment is increasing which means he/she has invested in areas other than those which are directly affected by interest rates.

- There exists a low degree of negative correlation between preference for a public sector bank and expected returns from investments. This implies that as the preference for public sector banks increases, the expected returns from investment also moves towards lower side.

- The correlation between preference for private sector bank and expected refurns is positive but of very low degree. This implies that higher preference for private sector banks is due, to increasing expected returns from investments.

- There is a low degree of positive correlation between the preference for foreign bank and expected returns. This implies that people prefer foreign banks because of their increasing returns expected from their investments.

- The correlation between public sector and private sector bank is negative and of low degree. Hence as preference for private sector bank increases, it leads to a consecutive lower preference for public sector banks.

- There exists a low degree of negative correlation between public sector bank and private sector bank. As preference for foreign bank increases, there shall be low preference for public sector banks.

- The correlation between private sector bank and foreign bank is of low degree and is negative which implies that as people prefer more of private sector banks, they shall foreign banks but to a lesser degree.

- Chi-Square Value: 26.01

Table Value: 21.026 
As the Chi-Square is greater than the table value, the null hypothesis rejected and the alternate hypothesis $(\mathrm{HI})$ is accepted. Thus it can be interpreted that the expected returns of the investor is dependant on his/ her annual income.

- Chi-Square Value: 6.802

Table Value: 16:919

Since calculated value is less than table value, the null hypothesis $(H O)$ is accepted. Hence the expected returns are independent of the age of the respondent.

- Chi-Square Value: 4.883

Table Value: 16.919

Since calculated value of Chi-Square is less than the table value. $\mathrm{HO}$ is accepted. Hence it can be interpreted as that the choice of bank deposit scheme is independent of the age of the respondent.

- Chi-Square Value: 0.517

Table Value: 7.815

Since calculated value of Chi-Square is less than the table value. $\mathrm{HO}$ is accepted. Hence it can be interpreted as that the choice of bank deposit scheme is independent of the gender of the respondent.

- Chi-Square Value: 11.93

Table Value: 21.026

Since calculated value of Chi-Square is less than the table value. $\mathrm{HO}$ is accepted. Hence it can be interpreted as that the choice of bank deposit scheme is independent of the occupation of the respondent.

- Chi-Square Value: 6.923

Table Value: 21.026

Since calculated value of Chi-Square is less than the table value. $\mathrm{HO}$ is accepted. Hence it can be interpreted as that the choice of bank deposit scheme is independent of the annual income of the respondent. 
- As the $F(24.15)>F c r i t(3.9)$, we reject $\mathrm{HO}$ and conclude that there is a significant difference between the change in investments in bank deposits in this financial year compared to previous financial year and investment in stock market which shall affect the value of investment in bank deposit in a bullish and a bearish trend.

- Since $F(0.978)<$ Fcrit(3.905), the null hypothesis is accepted.

Hence it can be concluded that there is no significant difference between the preference of bank deposit scheme and the occupation of the respondent

\section{Suggestions:}

- An increasing evidence of market integration implies that central banks can concentrate on the very short end of the yield curve. There is growing evidence in favour of co-movements of interest rates of different maturity. This has simultaneously increased monetary policy challenges, as central banks have to keep a watchful eye on all markets and be cautious of any cascading effect or contagion emerging in the domestic economy or originating in a foreign economy.

- An important issue is policy coordination between the fiscal and the monetary authorities. The stance of fiscal policy is important as it has a much broader spectrum of objectives. If fiscal authorities are the dominant players, monetary policy instruments are rendered less effective. As monetary policy evolves from a transitional setting of fiscal dominance, issues like direct access of government to central bank credit becomes important and crucial for fiscal-monetary coordination.

- Policy coordination is also an important issue facing economies linked by trade and capital flows. In an increasingly synchronized business cycle environment, international policy coordination becomes extremely important.

- Internationally, there has been more awareness that policy effectiveness is constrained by uncertainty. In fact, in many countries, the central bank projections are now published in the form of a fan chart rather than point estimates. 
- The concept of a bank cross-selling its third-party financial products to supplement its core business of accepting deposits and on-lending it to borrowers at a profit has come to be well recognised within the industry as a key component of a successful business strategy. It seeks to leverage a bank's core strength of a customer network to generate higher profits than may be inherent in the banking relationship that it may have with its customers.

- In the absence of a reference rate like Libor, banks in India price term loans and deposits mainly taking into account the credit risk and the asset-liability gap. An indicative rate or Mibor will help banks price loans and deposits in a more transparent way

- The depositor should know and understand well about his right to information, right to choose, right to avail/use the products and services, right to be heard and redressal of grievances.

- It is also essential for banks to penetrate all over the country in order to make people aware of the benefits of investment in bank deposits and thus provide all other ancillary financial services.

- Banks should consider investor's perspective in mind and formulate new products of investment based on deposit schemes in order to attract more investors.

- The investor should evaluate and compare all angles before investing in any investment avenue. Awareness and understanding is highly essential among investors.

- All' factors should be evaluated prior to investment in any investment avenue by taking into consideration the investment style, risk appetite, security, liquidity, tax saving. One factor shouldn't be compromised at the cost of another.

\section{Conclusions:}

In the current environment, monetary policy in India would continue to be vigilant and pro-active in the context of any accentuation of global uncertainties that pose threats to growth and stability in the domestic economy. The domestic outlook continues to be favorable and would dominate the dynamic setting of monetary policy in the period ahead. It is important to 
design monetary policy such that it promotes growth by contributing to the maintenance of financial and price stability. Accordingly, while the stance of monetary policy would confinue to reinforce the emphasis on price stability and well-anchored inflation expectations and thereby sustain the growth momentum, contextually, financial stability assumes greater importance at the current juncture.

Several transitions and structural transformation are taking place in the diverse and large society that is India. These encompass social, political, cultural and of course economic factors. Monetary policy is but one element in the complex web of challenges to public policy and there may be occasions when purely technical responses to monetary policy challenges would be less than appropriate. Public policy, including monetary policy, has to reckon with the complexity of managing these multiple transitions.

It is important to explore more formally the relationship among different segments of the markets and sectors of the economy, which will help in understanding the transmission mechanism of the monetary policy in India.

\section{References:}

1. Bernake, Blen and A. S. Blinder. (1988) Is It Money or Credit or Both or Neither. Credit Money and Aggregate Demand, AEA Papers and Proceedings.

2. Bernanke, B.S., and A.S. Blinder (1992). "The Federal Funds Rate and the Channels of Monetary Transmission." American Economic Review, 82, 4, 901-27.

3. Bernanke, B.S. and M.Gertler (1995). "Inside the Black Box: The Credit Channel of Monetary Policy Transmission." Journal of Economic Perspectives, 9(1), 27-48.

4. . Bernake, S. Gilchrist, and M. Gertler (1999) The Financial Accelerator in a Quantitative Business Cycles Framework, in Handbook of Macroeconomics Vol. 1 edited by J. B. Taylor and $\mathrm{M}$. Woodford.

5. Centre for Monitoring of Indian Economy. Prowess (Release 2.1), CMIE: Mumbai.

6. Dedola, L., and F.Lippi (2000). "The Monetary Transmission Mechanism: Evidence from the Industries of Five OECD Countries." (Unpublished; Rome: Bank of Italy).

7. Ganley, J., and C.Salmon (1997). "The Industrial Impact of Monetary Policy Shocks: Some Stylized Facts. Bank of England Working Paper No. 68, Bank of England: UK.

8. Huisman, J., and N. Hermes (1997). "Financial Liberalization in India and the Impact on the Business Environment." International Journal of Development Banking, 15 (1), 3-14. 
9. Kashyap, A.K., and J.C. Stein (1997). "What do a Million Banks have to say about the Transmission of Monetary Policy?" NBER Working Paper No.6056 (Cambridge, Mássachusetts: National Bureau of Economic Research).

10. Kashyap, A.K, J.C.Stein and D.W.Wilcox (1993). "Monetary Policy and Credit Conditions: Evidence from the Composifion of External Finance." American Economic Review, 83 (1), 73-98.

11. Kashyap, A.K., J.C. Stein and D.W. Wilcox (1996). "Monetary Policy and Credit Conditions: Evidence from the Composition of External Finance: Reply." AmericanEconomic Review, 86 (2), 310-314.

12. Khanna, T., and K. Palepu (2000). "Is Group Affiliation Profitable in Emerging Markets: An Analysis of Diversified Indian Business Groups?" Journal of Finance, 55 (2), 867. 891.

13. Kroszner, R.S., and P.E. Strahan (2001). "Bankers on Boards: Monitoring, Conflicts of Interests and Lender Liability." Journal of Financial Economics, 62 (3), 415-452.

14. Majumdar, S.K., (1997). "The Impact of Size and Age on Firm-Level Performance: Some Evidence from Indian Industry. "Review of Industrial Organisation, 12 (2), 231 241.

15. Mizen, P., and C. Yalcin (2002). "Corporate Finance when Monetary Policy Tightens: How Do Banks and Non-Banks Affect Access to Credit?" Working paper No.18, Experian Centre for Economic Modelling, University of Nottingham, UK.

16. Oliner, S.D., and G.D. Rudebusch (1996). "Is There a Broad Credit Channel for Monetary Policy?" Federal Reserve Bank of San Francisco Economic Review, 1, 4-13.

17. Rangarajan, C., (1988). "Issues in Monetary Management." Presidential Address at the 71 st Conference of Indian Economic Association, Delhi.

18. Reddy, Y.V., (2002). "Parameters of Monetary Policy in India." Lecture Delivered at the 88th Annual Conference of Indian Econometric Society, Chennai.

19. Sarkar, J., and S. Bhaumik (1998). "Deregulation and the Limits to Banking Sector Competition: Some Insights from India." International Journal of Development Banking. $16,29-42$. bv

20. Sims, C.A., and T. Zha (1998). "Does Monetary Policy Generate Recessions?" Federal Reserve Bank of Atlanta Working Paper No. 12.

21. Topalova, P., (2004). "Overview of the Indian Corporate Sector: 1989-2002." IMF Working Paper No. 64 (Washington: International Monetary Fund). 


\section{Web Sites:}

1. http://www.rbi.org.in/scripts/BS_ViewBulletin.aspx?ld =3342

2. http://www.rbi.org.in/scripts/BS_ViewBulletin.aspx? Id =8774

3. www.thehindubusinessline.com ,

4. www.banknetindia.com/banking/banking.htm

5. http://economictimes.indiatimes.com/ls_This_As_Good_As_It_Gets/ Next_big_opportunities_lie_in_rural_areas/articleshow/26 $\overline{6} 3340 . \mathrm{cms}$

6. http://en.wikipedia.org/wiki/Monetray_policy

7. www.businessstandard.com

8. http://www.zonkerala.com/articles/.

9. http://www.webindia123.com/finance/bank/fix.htm

10. http://www.indiaabroad.rediff.com/money/guest.html

11. www.indianexpress.com

12. http://www.managementparadise.com/forums/archive/index.php?t-13343.html 